Article

\title{
Comparative Analysis of Basic and Extended Power Models of Boreholes Expansion Dependence on Explosive Charge in Blasting in Clay Soil
}

\author{
Ivan Kovač ${ }^{1}$, Denis Težak ${ }^{1, *(1)}$, Josip Mesec ${ }^{1}$ and Ivica Markovinović ${ }^{2}$ \\ 1 Faculty of Geotechnical Engineering, University of Zagreb, Hallerova aleja 7, 42000 Varaždin, Croatia; \\ ivan.kovac@gfv.unizg.hr (I.K.); josip.mesec@gfv.unizg.hr (J.M.) \\ 2 Independent Researcher, Vidikovac 29, 43000 Bjelovar, Croatia; ivicam1901@gmail.com \\ * Correspondence: denis.tezak@gfv.unizg.hr
}

Received: 16 March 2020; Accepted: 16 April 2020; Published: 18 April 2020

check for updates

\begin{abstract}
Spherical cavities made by explosive charge activation in a clay soils differ in size and shape. The mass of explosive charge lowered on the bottom of the borehole in a one-time blasting is typically relatively small and is calculated by a desired and planned performace. The effect of smaller explosive charge for spherical cavities is in principle different than continuously filled borehole in mining and blasting operations. Detonation of smaller explosive charge crushes the material in proximity of activated explosive charge. With the increase of distance from the explosive charge, the released energy in not enough for crushing of the materials, but instead compacts it. This paper is an extension of the previous research, which resulted in a smallest error of estimated in a model shown as the sum of square residuals (SS), largest value of determination coefficient $\left(R^{2}\right)$ and smallest loss of information through Akaike's Information Criteria (AIC and $\mathrm{AIC}_{\mathrm{C}}$ ). This paper presents an extended power model of dependence of spherical cavity volume expansion on explosive charge. Extended model is a basic model with an additional parameter to ensure more precise mathematical description and further decrease of error of estimate for all efficiency indicators and for both types of explosive used.
\end{abstract}

Keywords: spherical cavity; clay soil; explosive charge; expansion dependency model; power model

\section{Introduction}

Spherical cavity blasting is one-time or multiple time blasting of small explosive charges at the bottom of the borehole with the purpose of expansion [1,2]. Detonation of the explosive charge at the bottom of the borehole results in a high value of pressure of detonation products [3,4]. The solid in the proximity of the explosive charge dislocates while more distant soil compreses [5], resulting in spherical cavity. The volume of the spherical cavity $\left(\mathrm{V}_{\mathrm{rc}}\right)$ depends on the mass and type of explosive charge $(Q)$ and geotechnical characteristics of the soil [6-9]. A diagram of relationship between the volume of spherical cavity and the mass of explosive charge has been made based on the results of spherical cavity blasting (Figure 1) [2].

Spherical volume increase made by spherical cavity blasting differ in shape and size, but in cohesive soils are typically spherical in shape [10]. The mass of explosive charge used in one-time spherical cavity blasting is usually small and determined by planned performace, typically between tens of grams to a couple of kilograms [11,12].

The research was carried out on the exploitation field Cukavec II, where exploitation of clay has been carried out for more than 50 years. The structure of the deposit is dominated by kaolinite, quartz, feldspar, and chlorite, and the granulometric composition shows that the mineral raw material contains 
about $75 \%$ of the clay component, while the rest is silt. The geotechnical properties of the clay soil were determined as part of the research. Cohesion c, internal friction angle $\varphi$ and volume weight $\gamma$ were determined. Cohesion is $c=23.4 \mathrm{KN} / \mathrm{m}^{2}$, internal friction angle $\varphi=19.8^{\circ}$, and volume weight $\gamma=18.7 \mathrm{KN} / \mathrm{m}^{3}$. Since the clay is hydroalumosilicate, which means that it absorbs water and therefore becomes brittle, the exploitation of the clay can only be carried out in dry months and when the air temperature is above $0{ }^{\circ} \mathrm{C}$ [13]. Spherical cavity blasting is rare in hard rocks. Namely, the effect of smaller explosive charge for spherical cavities is in principle different than continuously filled borehole in mining and blasting operations. Detonation of smaller explosive charge crushes the material in proximity of activated explosive charge. With the increase of distance from the explosive charge, the released energy is not enough for crushing materials, but instead compacts it $[4,11,12,14]$.

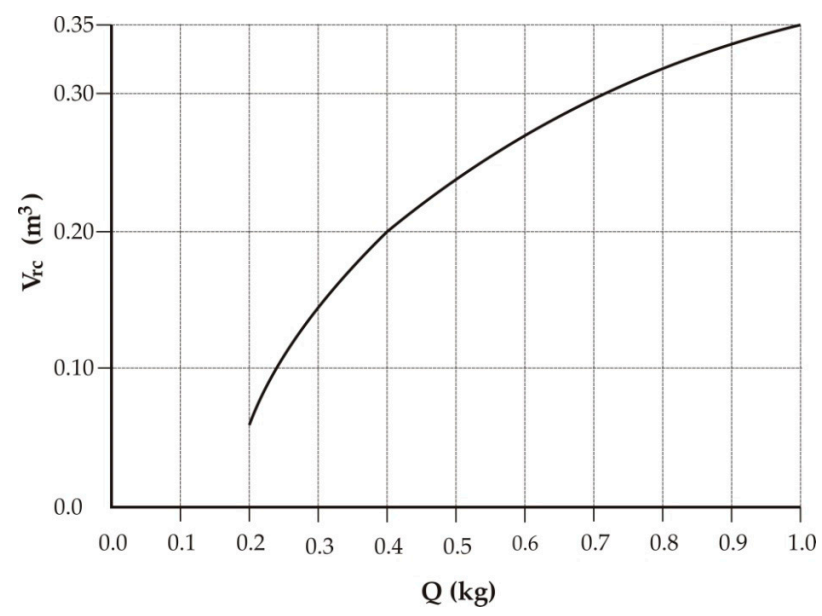

Figure 1. Diagram of relationship between the volume of spherical cavity $V_{r c}\left(\mathrm{~m}^{3}\right)$ and the mass of explosive charge $Q(\mathrm{~kg})[2]$.

Practical use of spherical cavity blasting in geotechnical works is in implementation of constructive elements for anchoring of foundation and retaining walls, permanent clay slope protection, and stabilization of different constructions such as transmission pole, tunnels, etc. [6,15].

Original data source, for the volume of spherical cavity $\left(\mathrm{V}_{\mathrm{rc}}\right)$, horizontal $\left(\mathrm{L}_{\mathrm{re}}\right)$, and vertical $\left(\mathrm{D}_{\mathrm{re}}\right)$ borehole increase, were obtained in field research from 2014 to 2016 [6,15]. Težak D. et al., 2019 [1] introduced the initial values of spherical cavity volume, horizontal, and vertical borehole increase. The inclusion of these values in the database resulted in the reduction of the error of estimation of the dependence of the boreholes expansion on the explosive charge during spherical cavity blasting. Two types of explosive charge were used: ANFO explosives commercially known as Pakaex and the Ammonia Nitrogen Powder Explosive Permonex V19. Technical specifications from the manufacturer for Pakaex: density $0.87 \mathrm{~g} / \mathrm{cm}^{3}$, VOD $2950 \mathrm{~m} / \mathrm{s}$, gas volume 984 1/kg, energy $3.7 \mathrm{~kJ} / \mathrm{kg}$ and for Permonex V19: density $0.95 \mathrm{~g} / \mathrm{cm}^{3}$, VOD $4500 \mathrm{~m} / \mathrm{s}$, gas volume $900 \mathrm{l} / \mathrm{kg}$, energy $4.2 \mathrm{~kJ} / \mathrm{kg}$ [14].

In all six cases, combinations of one of three efficiency indicators $\left(\mathrm{V}_{\mathrm{rc}}, \mathrm{L}_{\mathrm{re}}\right.$ and $\left.\mathrm{D}_{\mathrm{re}}\right)$ and type of explosive (Pakaex and Permonex V19), power model turned out to be the most efficient. Power model gives smallest estimation error values shown as the sum of square residuals (SS), largest values of determination coefficient $\left(\mathrm{R}^{2}\right)$ and smallest loss of information shown by Akaike's Information Criteria $\left(\mathrm{AIC}\right.$ and $\left.\mathrm{AIC}_{\mathrm{c}}\right)[1]$.

This work gives an extended power model of spherical cavity expansion dependence on explosive charge. Extended model is essentially just a basic model with an additional parameter. The purpose of introduction of additional parameter is to ensure more precise mathematical description of already mentioned dependence and further decrease of estimation error. The decrease of estimation error is important in the determination of explosive mass used for spherical cavity blasting and coherent soil 
compaction. The smaller the estimation error, the more efficient and precise predicition of needed explosive mass can be made.

Based on existing analysis and an extended model, three analysis variants of a relationship between the volume of spherical cavity and explosive charge can be made:

1. Basic database-basic model

2. Extended database-basic model

3. Extended database-extended model

Obtained results are compared and justification of introduction of new parameters in the model was made.

\section{Previous Research}

Other than performed research from 2014 to 2016 [15], and researche in Težak, D. 2018 [6] and Težak, D. et al. 2019 [1], there are a couple of similar methods found in literature.

Literature review shows works that deal with improvements of geotechnical properties of soils using released energy in detonation of explosive charge. This is known as explosive compaction (EC). EC is a technique of soil modification that relies on explosive charge detonation to compact surrounding soft soil [16]. It should be noted, from the literature, that the explosive compaction method (EC) is used less frequently than other construction methods, primary vibrational methods, deep soil mixing (DSM), deep dynamic compaction (DDC), or jet grouting.

Literature review also showed the use of three-dimensional (3D) visualization method of natural discontinuities in a rock buring borehole drilling. This is very useful for easier and more predictable drilling plan and hydraulic fracture control [17]. Another work shows a combined interpretation of core images and acoustic images of the borehole wall for characterization of rock structure [18].

For the purpose of Težak, D. 2018 [6] doctoral thesis, application "Bušotine" was created which gives a detail 3D representation and volume of spherical cavity. Similar development of application was found in a literature review. For example, application "The BoreIs" was developed [19] as an extension to the ESRI Arcscenes three-dimensional (3D) GIS environments. It is mostly used by geologists to find spatial patterns in their data, beyond the limits of data tables and flat maps.

\section{Extended Power Model}

The research was conducted on an exploitation field Cukovec II, near the city of Varaždin. During the research from 2014 to 2016, obtained field data were used to broaden the knowledge of effects of explosive charge in clay soils and of possible usage of certain types of explosives in geotechnical practice [15]. The area of interest was blasted in soft rock in order to create spherical volume cavities using different types and masses of explosive. Collection of all the field data and the innovative approach in data processing were published in Težak D. et al., 2019 [1].

Plan and methods of field research, as well as data processing, are shown in Mesec J. et al., 2015 [15], Težak D., 2018 [6]. Data used in data processing are shown in Table 1. Every spherical increase of a borehole has initial value of spherical volume $\left(\mathrm{V}_{\mathrm{rc} 0}\right)$, horizontal $\left(\mathrm{L}_{\mathrm{re} 0}\right)$, and vertical $\left(\mathrm{D}_{\mathrm{re} 0}\right)$ borehole increase, all shown in blue in Table 1 [1]. 
Table 1. The results of spherical cavity blasting for explosives Pakaex and Permonex V19 [1].

\begin{tabular}{|c|c|c|c|c|c|c|c|c|c|}
\hline \multicolumn{5}{|c|}{ Pakaex } & \multicolumn{5}{|c|}{ Permonex V19 } \\
\hline Borehole & $\begin{array}{c}\text { Explosive } \\
\text { Charge Mass }\end{array}$ & $\begin{array}{c}\text { Volume of } \\
\text { the Resulting } \\
\text { Cavity }\end{array}$ & $\begin{array}{l}\text { Resulting } \\
\text { Expansion of } \\
\text { the Borehole }\end{array}$ & $\begin{array}{c}\text { Deepening of } \\
\text { the Resulting } \\
\text { Expansion }\end{array}$ & Borehole & $\begin{array}{c}\text { Explosive } \\
\text { Charge Mass }\end{array}$ & $\begin{array}{c}\text { Volume of } \\
\text { the Resulting } \\
\text { Cavity }\end{array}$ & $\begin{array}{l}\text { Resulting } \\
\text { Expansion of } \\
\text { the Borehole }\end{array}$ & $\begin{array}{c}\text { Deepening of } \\
\text { the Resulting } \\
\text { Expansion }\end{array}$ \\
\hline & $\begin{array}{c}Q \\
(\mathbf{k g})\end{array}$ & $\begin{array}{c}V_{\mathrm{rc}} \\
\left(\mathrm{m}^{3}\right)\end{array}$ & $\begin{array}{l}\mathrm{L}_{\mathrm{re}} \\
(\mathrm{m})\end{array}$ & $\begin{array}{l}D_{\text {re }} \\
\text { (m) }\end{array}$ & & $\underset{(\mathrm{kg})}{\mathrm{Q}}$ & $\begin{array}{c}V_{\mathrm{rc}} \\
\left(\mathrm{m}^{3}\right)\end{array}$ & $\begin{array}{l}\mathrm{L}_{\mathrm{re}} \\
(\mathrm{m})\end{array}$ & $\begin{array}{l}D_{\text {re }} \\
\text { (m) }\end{array}$ \\
\hline MB20 & 1.00 & 0.7100 & 1.1570 & 0.5200 & MB24 & 0.80 & 0.6184 & 1.1900 & 0.3100 \\
\hline MB41 & 1.00 & 0.8095 & 1.1110 & 0.6000 & MB26 & 0.80 & 0.5690 & 1.1310 & 0.3600 \\
\hline MB34 & 0.80 & 0.3935 & 0.9530 & 0.3300 & MB45 & 0.80 & 0.7405 & 1.0700 & 0.4000 \\
\hline MB18 & 0.80 & 0.3440 & 0.8770 & 0.4600 & PMB5 & 0.80 & 0.7227 & 1.0710 & 0.4200 \\
\hline MB19 & 0.80 & 0.3626 & 0.8750 & 0.4800 & MB23 & 0.60 & 0.5276 & 1.1040 & 0.3500 \\
\hline MB40 & 0.80 & 0.5190 & 1.0600 & 0.4000 & MB25 & 0.60 & 0.6330 & 1.0850 & 0.2900 \\
\hline MB35 & 0.60 & 0.2555 & 0.7830 & 0.2500 & PMB6 & 0.60 & 0.6151 & 1.1520 & 0.3500 \\
\hline MB17 & 0.60 & 0.6160 & 1.0430 & 0.3400 & MB36 & 0.40 & 0.1135 & 0.6930 & 0.2300 \\
\hline MB39 & 0.60 & 0.3785 & 1.0880 & 0.4000 & MB21 & 0.40 & 0.2925 & 0.9360 & 0.2600 \\
\hline MB15 & 0.40 & 0.2445 & 0.6980 & 0.3100 & MB27 & 0.40 & 0.2160 & 0.5850 & 0.3200 \\
\hline MB16 & 0.40 & 0.1945 & 0.7870 & 0.3000 & MB43 & 0.40 & 0.2815 & 0.8660 & 0.3000 \\
\hline MB38 & 0.40 & 0.2980 & 0.8480 & 0.4000 & MB22 & 0.20 & 0.0825 & 0.5570 & 0.2600 \\
\hline MB13 & 0.20 & 0.1005 & 0.5760 & 0.1800 & MB28 & 0.20 & 0.0700 & 0.5050 & 0.2200 \\
\hline MB14 & 0.20 & 0.0645 & 0.5770 & 0.2200 & MB42 & 0.20 & 0.1480 & 0.6620 & 0.2000 \\
\hline MB29 & 0.20 & 0.0980 & 0.6870 & 0.2400 & - & 0.00 & 0.0005 & 0.1310 & 0.0390 \\
\hline MB37 & 0.20 & 0.1175 & 0.6010 & 0.2500 & & & & & \\
\hline- & 0.00 & 0.0007 & 0.1310 & 0.0390 & & & & & \\
\hline
\end{tabular}


Data was processed using a power model. Basic power model is given as:

$$
y=a \cdot x^{b}
$$

This basic model is also shown in a Figure 2 and it can be clearly seen that the curve passes through the coordinate system origin point. Initial values of spherical volume increase $\left(\mathrm{V}_{\mathrm{rc}}\right)$, horizontal $\left(\mathrm{L}_{\mathrm{re}}\right)$, and vertical $\left(\mathrm{D}_{\mathrm{re}}\right)$ borehole increase are shown as point data on the ordinate. Basic power model was extended with addition of a new parameter (c):

$$
y=a \cdot x^{b}+c
$$

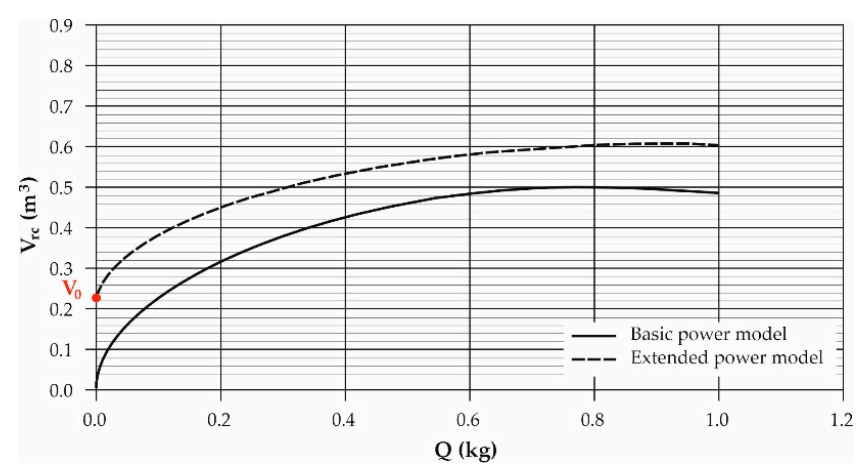

Figure 2. Schematic of basic and extended power model for spherical cavity volume increase $V_{r c}\left(\mathrm{~m}^{3}\right)$ in dependence on the mass of explosive charge $Q(\mathrm{~kg})$.

The curve of extended power model passes through some point on the ordinate of the coordinatey system. Values of model parameters are determined by least square method in program package Statistica V 13.5 [20].

Different models are compared on the basis of determination coeficients values $\left(R^{2}\right)$ shown in Tables 2 and 3. However, that value increases with the increase of number of parameters in the model and can only be used to compare the models with the same number of parameters. Since there is a difference between the basic and extended models, it is necessary to compare both on the basis of Akaike's Information Criteria (AIC) which also takes into account the number of parameters [21-24]:

$$
A I C=N \cdot \ln \frac{S S}{N}+2 \cdot K,
$$

where: $K$ —the number of paramters in the model and SS—sum of square residuals:

$$
S S=\sum_{i=1}^{N}\left(y_{i}-\hat{y}_{i}\right)^{2},
$$

where: $y_{i}$ - measured value and $\hat{y}_{i}$ - estimated value of the model.

Furthermore, when $N$ is not much larger than $K$, corrected AIC is applied:

$$
A I C_{c}=A I C+\frac{2 \cdot K \cdot(K+1)}{N-K+1},
$$

It can be noticed that with the increase between the values of $\mathrm{N}$ and $\mathrm{K}$, the second term in the equation decreases:

$$
N \gg K,
$$

The value of the second term can be neglected. However, it should be noted that the criteria "much larger" is not clearly defined in the literature (as far as known to the authors). Due to that 
fact, results for both criteria are shown in the paper. Obtainted values for $S S, R^{2}, A I C$, and $A I C_{c}$ are determined and shown for both types of explosive charge seperately (Tables 2 and 3 ). Between the two models, the one that gives lesser values of $A I C$ and $A I C_{c}$ is considered superior.

\section{Results and Discussion}

In Težak D. et al., 2019 [1] for the purpose of analysing the effects of spherical cavity blasting, a mathematical model was made that describes the relationship between volume increase of a borehole and mass of the explosive charge. The aim of this paper was to establish a relationship between the increase volume of a spherical volume and mass of explosive charge, type of explosive used and its detonation and mining-technical parameters. In all the calculated models, the lowest value of $A I C_{c}$ was for the extended model. That result justifies the addition of constant to the function argument as a new model parameter.

Introduction of the new parameter had an impact on the error of estimate value. The error is smaller in value in extended models, compared to the basic models, which can be seen from the sum of square residuals (column SS, Tables 2 and 3). In Tables 2 and 3, the yellow colour emphasizes the best values of sums of square residuals (SS), values of determination coefficient $\left(R^{2}\right)$, and values of Akaike's Information Criteria (AIC and AICc).

Table 2. Parameter values and results of the power model analysis for explosive charge Pakaex.

\begin{tabular}{cccccccccc}
\hline \multicolumn{2}{c}{$\begin{array}{c}\text { Pakaex } \\
(\mathbf{N}=\mathbf{1 7})\end{array}$} & $\mathbf{a}$ & $\mathbf{b}$ & $\mathbf{c}$ & $\mathbf{K}$ & $\mathbf{S S}$ & $\mathbf{R}^{2}$ & AIC $^{2}$ & AIC $_{\mathbf{c}}$ \\
\hline \multirow{2}{*}{$\mathrm{V}_{\mathrm{rc}}$} & 1 & 0.66 & 0.66 & - & 2 & 0.170 & 0.770 & -68.700 & -67.900 \\
& 2 & 0.66 & 1.20 & - & 2 & 0.170 & 0.800 & -74.278 & -73.528 \\
& 3 & 0.64 & 1.32 & 0.02 & 3 & 0.169 & 0.804 & -74.358 & -72.758 \\
\hline \multirow{2}{*}{$\mathrm{L}_{\mathrm{re}}$} & 1 & 1.09 & 0.35 & - & 2 & 0.130 & 0.780 & -72.920 & -72.120 \\
& 2 & 1.09 & 0.35 & - & 2 & 0.148 & 0.863 & -76.667 & -75.917 \\
& 3 & 0.96 & 0.42 & 0.13 & 3 & 0.131 & 0.878 & -76.718 & -75.118 \\
\hline \multirow{2}{*}{$\mathrm{D}_{\mathrm{re}}$} & 1 & 0.50 & 0.53 & - & 2 & 0.060 & 0.720 & -85.920 & -85.120 \\
& 2 & 0.50 & 0.53 & - & 2 & 0.060 & 0.804 & -92.130 & -91.380 \\
& 3 & 0.45 & 0.64 & 0.05 & 3 & 0.057 & 0.812 & -90.894 & -89.294 \\
\hline
\end{tabular}

$\mathrm{V}_{\mathrm{rc}}$, made spherical volume; $\mathrm{L}_{\mathrm{re}}$, horizontal borehole increase; $\mathrm{D}_{\mathrm{re}}$, vertical borehole increase.

Table 3. Parameter values and results of the power model analysis for explosive charge Permonex V19.

\begin{tabular}{|c|c|c|c|c|c|c|c|c|c|}
\hline \multicolumn{2}{|c|}{$\begin{array}{c}\text { Permonex V19 } \\
\quad(\mathrm{N}=15)\end{array}$} & \multirow{2}{*}{$\begin{array}{c}\mathbf{a} \\
0.94\end{array}$} & \multirow{2}{*}{$\begin{array}{c}\mathbf{b} \\
0.21\end{array}$} & \multirow{2}{*}{$\begin{array}{l}\mathrm{c} \\
-\end{array}$} & \multirow{2}{*}{$\begin{array}{l}\mathbf{K} \\
2\end{array}$} & \multirow{2}{*}{$\begin{array}{c}\text { SS } \\
0.110\end{array}$} & \multirow{2}{*}{$\begin{array}{c}\mathbf{R}^{2} \\
0.870\end{array}$} & \multirow{2}{*}{$\begin{array}{c}\text { AIC } \\
-64.260\end{array}$} & \multirow{2}{*}{$\begin{array}{c}\mathrm{AIC}_{\mathrm{c}} \\
-63.340\end{array}$} \\
\hline & 1 & & & & & & & & \\
\hline $\mathrm{V}_{\mathrm{rc}}$ & 2 & 0.94 & 1.32 & - & 2 & 0.110 & 0.891 & -70.173 & -69.316 \\
\hline & 3 & 0.96 & 1.22 & -0.03 & 3 & 0.105 & 0.893 & -70.399 & -68.553 \\
\hline \multirow{3}{*}{$\mathrm{L}_{\mathrm{re}}$} & 1 & 1.30 & 0.51 & - & 2 & 0.160 & 0.810 & -59.010 & -58.090 \\
\hline & 2 & 1.30 & 0.51 & - & 2 & 0.170 & 0.870 & -62.972 & -62.115 \\
\hline & 3 & 1.18 & 0.59 & 0.12 & 3 & 0.157 & 0.885 & -62.384 & -60.538 \\
\hline \multirow{3}{*}{$\mathrm{D}_{\mathrm{re}}$} & 1 & 0.40 & 0.37 & - & 2 & 0.020 & 0.710 & -90.320 & -89.410 \\
\hline & 2 & 0.40 & 0.37 & - & 2 & 0.018 & 0.853 & -96.798 & -95.941 \\
\hline & 3 & 0.36 & 0.43 & 0.04 & 3 & 0.017 & 0.866 & -96.187 & -94.472 \\
\hline
\end{tabular}

$\mathrm{V}_{\mathrm{rc}}$, made spherical volume; $\mathrm{L}_{\mathrm{re}}$, horizontal borehole increase; $\mathrm{D}_{\mathrm{re}}$, vertical borehole increase.

The reason behind the decrease is obvious while estimating the initial value. Namely, in the basic model, the graph of the model traces through the coordinate system origin point (Figure 2), and the error of estimate for $Q=0$ is the initial value. In the extended model, the graph traces through some point on the ordinate and that is the value of parameter $c$ (Figure 2).

In five out of six presented cases, the difference between the initial value and its estimation is lower than the initial value itself (column c of Table 3, Figures 3 and 4). The only exception is the 
extended model of spherical volume increase of a borehole for Permonex V19. In that case, the negative value of initial parameters was obtained (column c, Table 3, Figure 4a). Consequently, the estimation for $Q=0$ is larger than the initial value. However, the sum of square residuals is still lower in the extended model, which confirmes the justification of introducing the new parameter.

Introduction of the new parameter in the power model also resulted in higher values of determination coefficient in extended models, compared to the basic models (column $\mathrm{R}^{2}$, Tables 2 and 3 ). This difference was expected, since the value of the coefficient increases with the increase of numbers of parameters in the model. This is the reason behind using $A I C$ and $A I C_{c}$ for comparison.

The extension of the model caused the decrease in error of estimate, but also the increase in the number of the parameters. It is clear from the $A I C$ and $A I C_{c}$ expressions that their values are proportional to the error of estimate value and the number of the parameters. For that reason, it is necessary to establish whether reduction of error of estimated value is sufficient to justify the implementation of the new parameter.

The values of $A I C$ and $A I C_{c}$ are listed in Tables 2 and 3 in separate columns. Lower $A I C$ values were obtained for extended models for spherical volume increase for both explosive charges and horizontal borehole increase for Pakaex. However, $A I C_{c}$ lower values for basic models were obtained for all cases.

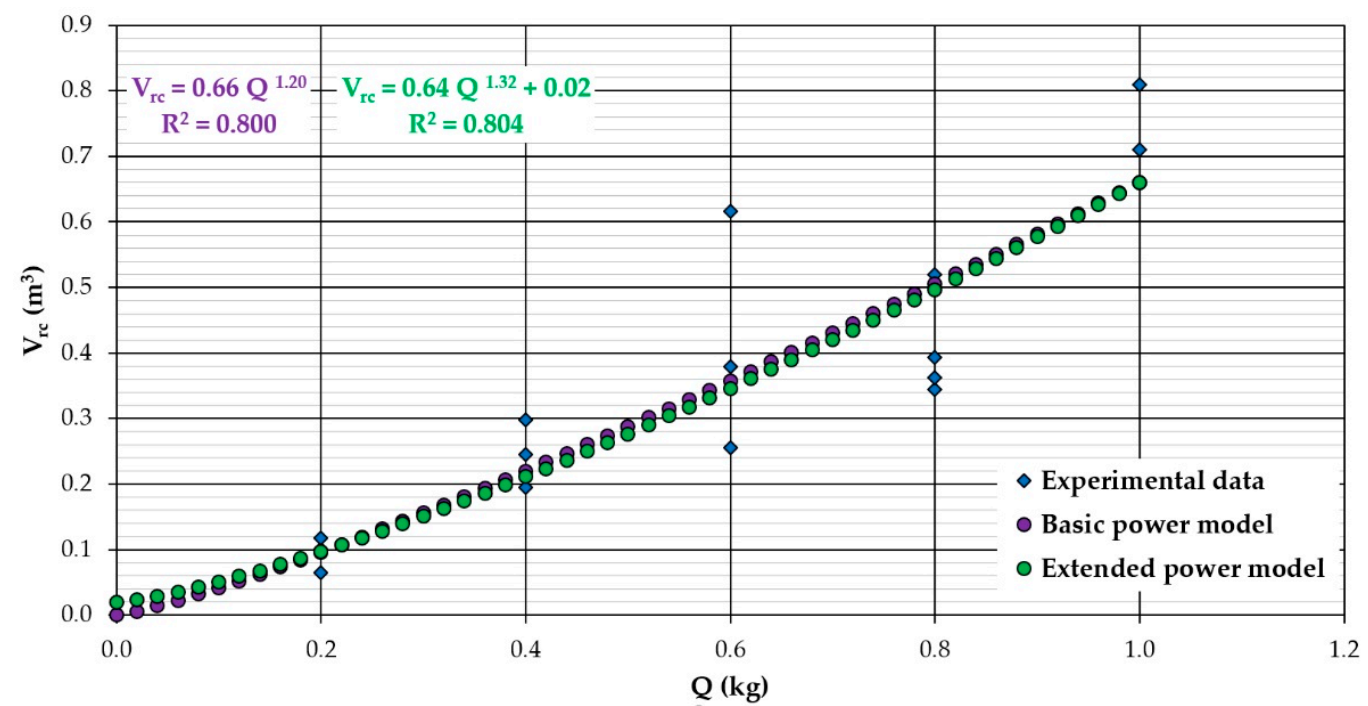

(a)

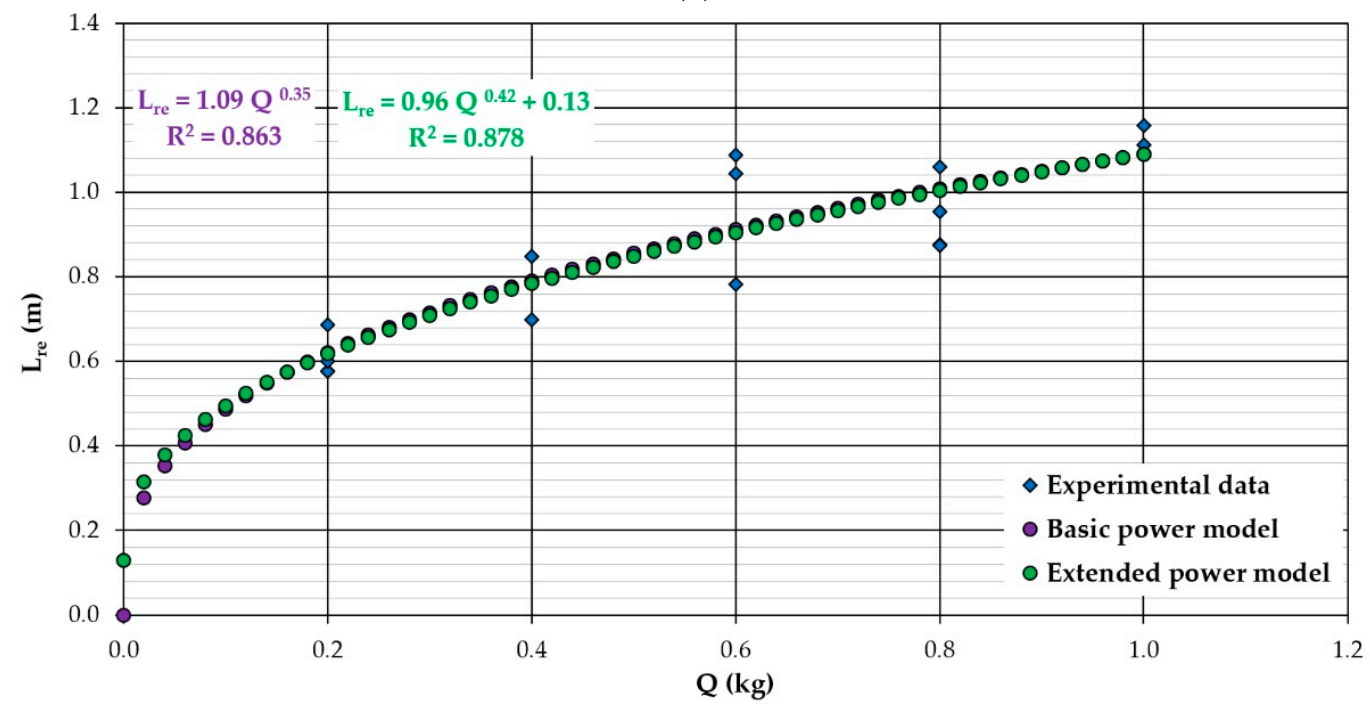

(b)

Figure 3. Cont. 


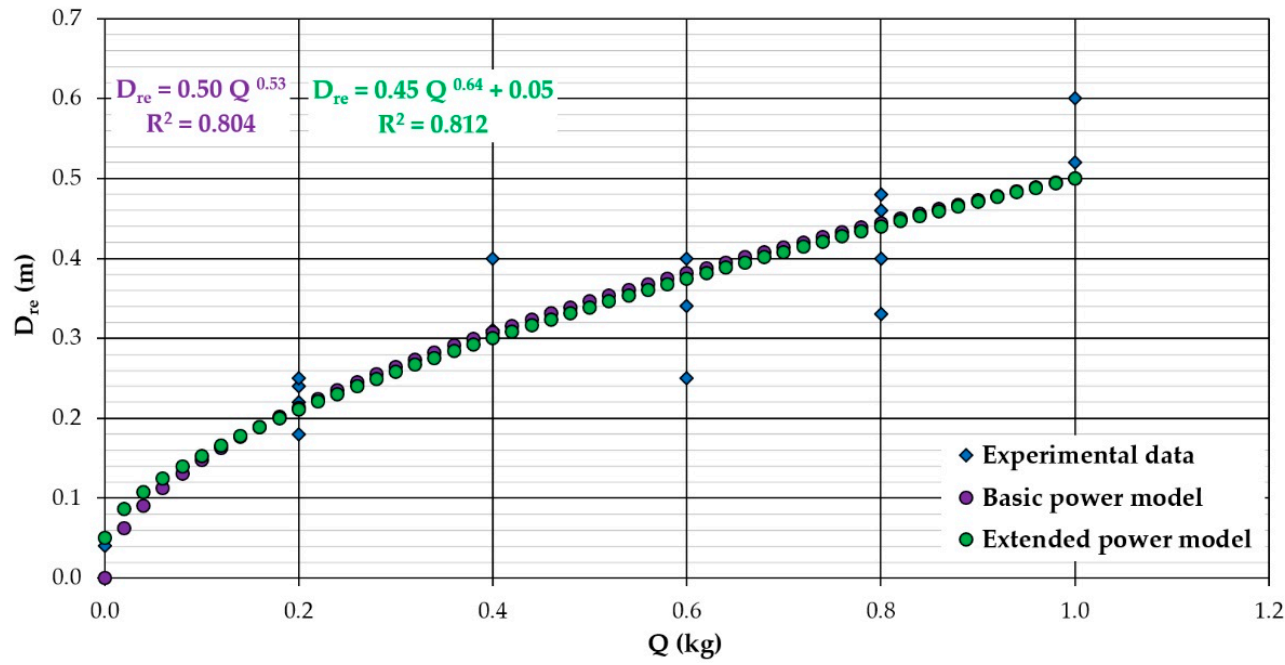

(c)

Figure 3. Basic and extended power model for Pakaex: (a) Spherical volume increase; (b) Borehole horizontal increase; (c) Borehole vertical increase.

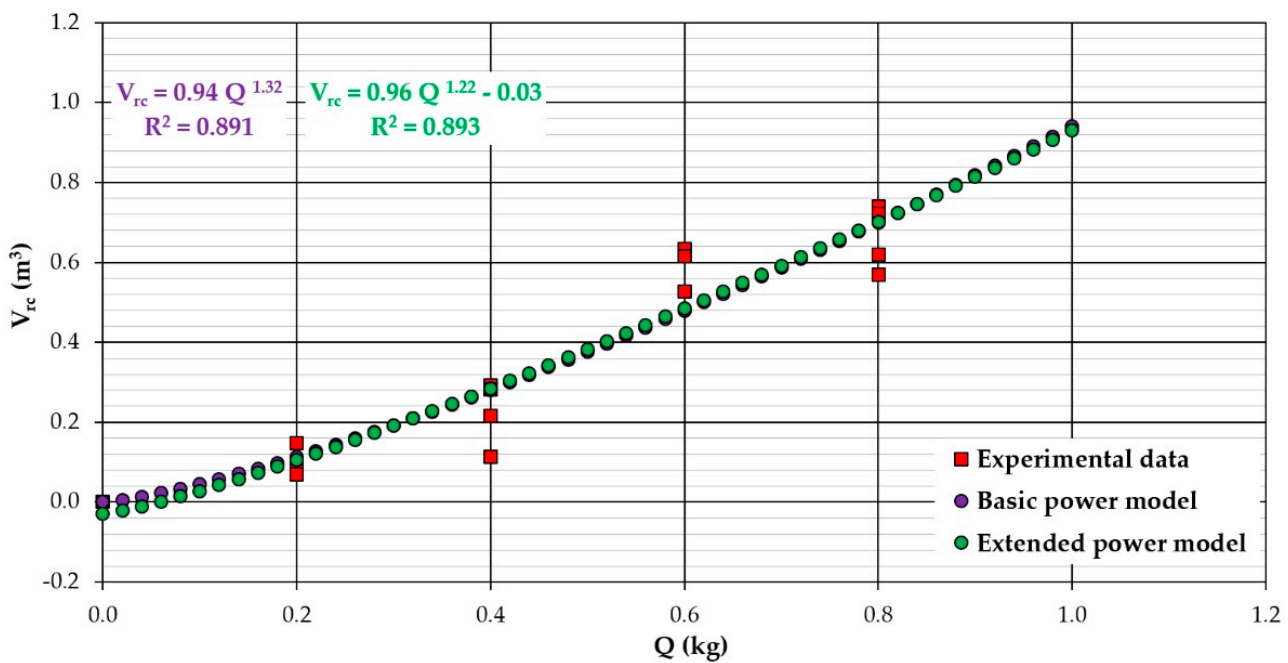

(a)

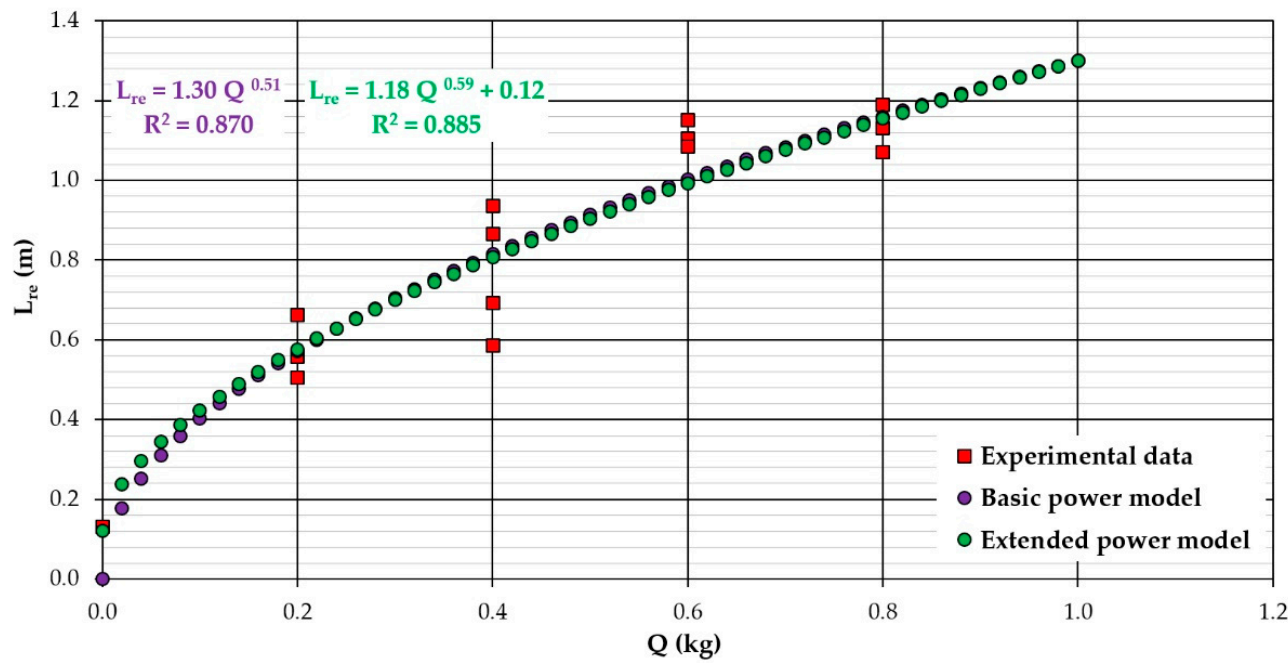

(b)

Figure 4. Cont. 


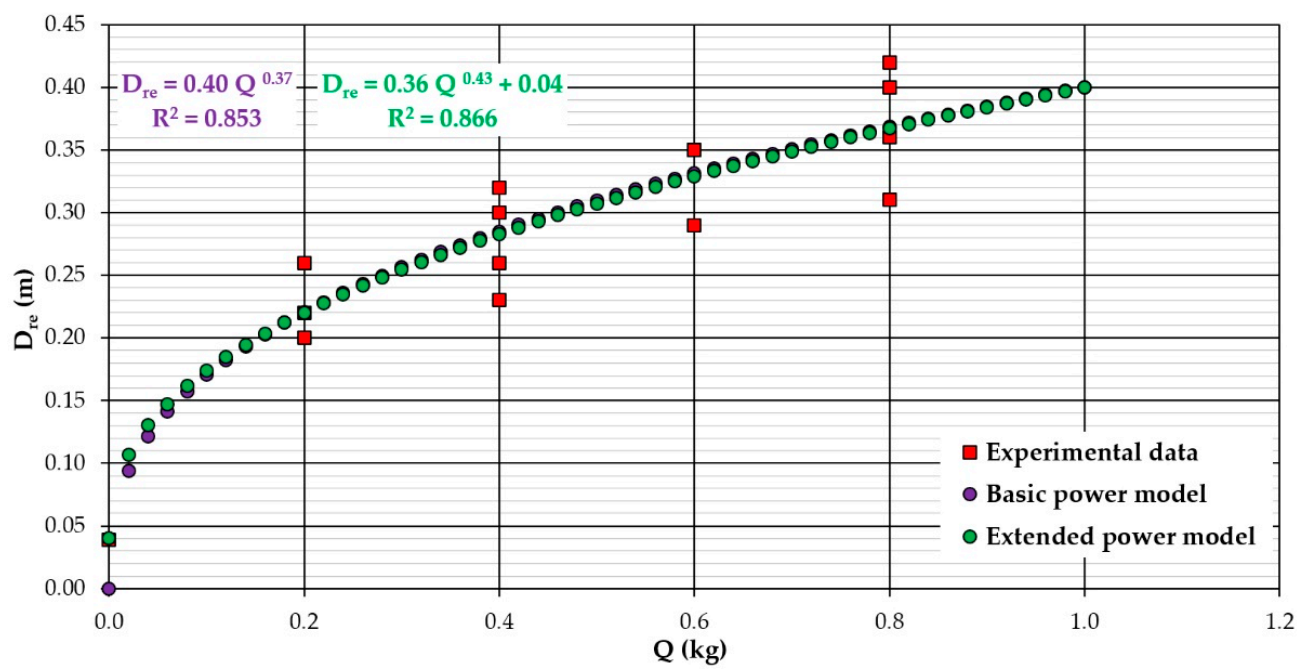

(c)

Figure 4. Basic and extended power model for Permonex V19: (a) Spherical volume increase; (b) Borehole horizontal increase; (c) Borehole vertical increase.

\section{Conclusions}

Previous papers showed different dependency models on spherical volume increase in boreholes for two different types of explosives, and the power model turned out to be the most successful. Justification of introduction of intial values in a database was also analysed. Each of those values are presented as a point data on an ordinate in a dispersion diagram. Obtained results show that introduction of a new parameter was justified.

The curve representing the basic power model runs through the coordinate system origin point. Due to this fact, there is a difference between the estimated values using the basic model and the initial value. In order to decrease that difference, a new parameter was introduced in the basic model, resulting in an extended power model whose cure runs through some point on the ordinate of the coordinate system.

Introduction of the new parameter into the model resulted in error of estimate reduction in five out of six cases and in an increase of determination coefficient in all cases. This confirms the main purpose of this paper: improved mathematical description of dependence of expansion of a borehole to explosive charge. This gives the possibility of better estimation of mass of explosive needed in an explosive charge in geotechnical practice, as well as faster and more efficient spherical cavity blasting.

For all shown effects of blasting for both types of explosive charge, Pakaex and Permonex V19, higher values of determination coefficient were obtained. This confirms the successful achievement of a mathematically better description of the relationship between spherical cavity blasting and explosive charge.

Comparison of obtained AIC values for basic and extended models shows that introduction of a new parameter was at least partly justified. In three out of six models, lower values of AIC for the extrended models were obtained. However, in all six cases, lower values of $A I C_{c}$ were obtained for the basic models, making the basic model superior and the introduction of the new parameter not completely justifiable.

In conclusion, it is necessary to build a model that demonstrates the relationship between spherical cavity blasting and explosive charge that will result in the smallest value of error of estimate and also in the lowest $A I C$ and $A I C_{c}$ values. 
Author Contributions: Conceptualization, I.K.; Data curation, J.M.; Formal analysis, I.K.; Investigation, D.T.; Methodology, I.K.; Project administration, J.M.; Resources, D.T.; Software, D.T.; Supervision, J.M.; Validation, I.M.; Visualization, I.M.; Writing-original draft, I.K. and D.T.; Writing—review and editing, I.M. All authors have read and agreed to the published version of the manuscript.

Funding: This research received no external funding.

Acknowledgments: Publication process is supported by the Faculty of Geotechnical Engineering, University of Zagreb.

Conflicts of Interest: The authors declare no conflict of interest.

\section{References}

1. Težak, D.; Stanković, S.; Kovač, I. Dependence Models of Borehole Expansion on Explosive Charge in Spherical Cavity Blasting. Geosciences 2019, 9, 383. [CrossRef]

2. Krsnik, J. Miniranje; University of Zagreb: Zagreb, Croatia, 1989; ISBN 8680891088.

3. Li, Q.; Li, Y.; Dasgupta, G.; Song, D.; Qiao, L.; Wang, L.; Dong, J. Analysis of the Blasting Compaction on Gravel Soil. J. Chem. 2015. [CrossRef]

4. Dobrilović, M.; Bohanek, V.; Žganec, S. Influence of Explosive Charge Temperature on Velocity of Detonation of ANFO Explosive. Cent. Eur. J. Energetic Mater. 2014, 11, 191-198.

5. Wang, Z.; Lu, Y. Numerical analysis on dynamic deformation mechanism of soils under blast loading. Soil Dyn. Earthqake Eng. 2003, 23, 705-714. [CrossRef]

6. Težak, D. Influence of the Blasting Features on the Expansion in Clay Soil. Ph.D. Thesis, University of Zagreb, Faculty of Mining, Geology and Petroleum Engineering, Zagreb, Croatia, 2018.

7. Frgić, L.; Hudec, M.; Krsnik, J.; Krajcer, M.; Mesec, J. Underground grounding by anchoring in soil. In Proceedings of the I Yugoslavian Symposium on Tunnels, Brijuni, Croatia, 24-26. November 1988; pp. 293-298.

8. Bakr, R.M. The Impact of the unsupported excavation on the boundary of the active zone in medium, stiff and very stff clay. J. Civ. Environ. Eng. 2019, 9,1-9.

9. Soltani, A.; Deng, A.; Taheri, A.; Mirzababaei, M.; Vanapalli, S.K. Swell-Shrink Behavior of Rubberized Expansive Clays During Alternate Wetting and Drying. Minerals 2019, 9, 224. [CrossRef]

10. Araya, K.; Gao, R.; Tsunematsu, S.; Ochi, K. Loosening of dense clay soils by linear blasting. J. Agric. Eng. Res. 1993, 54, 113-126. [CrossRef]

11. Sućeska, M. Eksplozije i Eksplozivi-Njihova Mirnodopska Primjena; Brodarski Institut: Zagreb, Croatia, 2001; ISBN 953-6017-11-3.

12. Dobrilović, M. Raspoloživa energija tlačnog udarnog vala udarne cjevčice i njezina primjena u iniciranju elektroničkog detonatora. Ph.D. Thesis, University of Zagreb, Zagreb, Croatia, 2008.

13. Težak, D.; Soldo, B.; Đurin, B.; Kranjčić, N. Impact of Seasonal Changes of Precipitation and Air Temperature on Clay Excavation. Sustainability 2019, 11, 6368. [CrossRef]

14. Žganec, S.; Bohanek, V.; Dobrilović, M. Influence of a Primer on the Velocity of Detonation of ANFO and Heavy ANFO Blends. Cent. Eur. J. Energ. Mater. 2016, 13, 694-704. [CrossRef]

15. Mesec, J.; Težak, D.; Grubešić, M. The use of explosives for improvement of clay soils. Environ. Eng. 2015, 2, 95-101. (In Croatia)

16. Shakeran, M.; Eslami, A.; Ahmadpour, M. Geotechnical Aspects of Explosive Compaction. Shock Vib. 2016, 2016, 6719271. [CrossRef]

17. Wu, H.; Pollard, D.D. Imaging 3-D fracture networks around boreholes. Am. Assoc. Pet. Geol. 2002, 4, 593-604.

18. Schepers, R.; Rafat, G.; Gelbke, C.; Lehmann, B. Application of borehole logging, core imaging and tomography to geotechnical exploration. Int. J. Rock Mech. Min. Sci. 2001, 38, 867-876. [CrossRef]

19. McCarthy, J.D.; Graniero, P.A. A GIS-based borehole data management and 3D visualization system. Comput. Geosci. 2006, 32, 1699-1708. [CrossRef]

20. Statistica V 13.5. Available online: http://www.statsoft.com/Products/STATISTICA-Features (accessed on 5 December 2019). 
21. Akaike, H. Information theory and an extension of the maximum likelihood principle. In Proceedings of the 2nd International Symposium on Information Theory, Tsahkadsor, Armenia, USSR, Budapest, Hungary, 2-8 September 1971; Akadémiai Kiadó: Budapest, Hungary; pp. 267-624.

22. Akaike, H. A new look at the statistical model identification. IEEE Trans. Autom. Control 1974, 19, 716-723. [CrossRef]

23. Findley, D.F.; Parzen, E. A conversation with Hirotugu Akaike. Stat. Sci. 1995, 10, 104-117. [CrossRef]

24. Cavanaugh, J.E. Unifying the derivations of the Akaike and corrected Akaike information criteria. Stat. Probab. Lett. 1997, 31, 201-208. [CrossRef]

(C) 2020 by the authors. Licensee MDPI, Basel, Switzerland. This article is an open access article distributed under the terms and conditions of the Creative Commons Attribution (CC BY) license (http://creativecommons.org/licenses/by/4.0/). 